\title{
FIRST RECORD OF CYANOBACTERIA MICROBORING ACTIVITY IN PAMPEAN SHALLOW LAKES OF ARGENTINA
}

\author{
ELEONOR TIETZE \\ Instituto de Investigaciones Marinas y Costeras (IIMyC) - CONICET, Universidad Nacional de Mar del Plata, \\ Juan B. Justo 2250 (CP7600), Mar del Plata, Argentina. \\ etietze@mdp.edu.ar \\ KARINA SOLEDAD ESQUIUS \\ Laboratorio de Limnología, Instituto de Investigaciones Marinas y Costeras (IIMyC) - CONICET \\ Universidad Nacional de Mar del Plata, Funes 3250, segundo piso (CP 7600), Mar del Plata, Argentina. \\ kesquius@mdp.edu.ar
}

\begin{abstract}
Bioerosion led by cyanobacteria occurs in terrestrial, freshwater and marine environments and depends on several ecological and climatic conditions. Therefore, the traces left by these boring organisms can give additional information about the paleoenvironment. In the case of freshwater environments of Argentina, the dissolution of mollusk shells has mainly been attributed to chemical and biological processes. The effect of microbioerosion processes in taphonomic lost is still lacking. With the aim of identifying microbioerosion processes, mollusk shells were studied. The specimens collected were specially picked when a biofilm covered the shell or dissolution marks were present. The shell surface of some specimens were scrapped removing the biofilm or the shells were dissolved with $\mathrm{HCl}$, and the biological remains were observed under light microscope. Other specimens were treated with $2.5 \%$ sodium hypochlorite to remove organic matter, and then coated with gold and analyzed using a scanning electronic microscope. Surface pitting and circular to ovoid penetrations were observed. The endolithic cyanobacteria found could be identified as belonging to the family Pseudanabaenaceae. This is the first record of microbioerosion borings in shells of Heleobia parchappii in a pampean shallow lake, and the presence of the trace produced producing cyanobacteria. The record of this endolithic bioerosion traces enhances the discussion of taphonomic processes affecting mollusk shells in freshwater settings, and may allow adjusting the composition of fossil assemblages and in consequence paleoecological interpretations.
\end{abstract}

Keywords: microbioerosion, freshwater environments, mollusks, Pampean Region, taphonomy.

\section{INTRODUCTION}

The taphonomic processes that occur in the first centimeters of sediment below the sediment-water interface (i.e. the benthic taphonomically active zone, TAZ, Davies et al., 1989) constitute a barrier for the preservation of recently dead organisms. These early diagenetic processes tend to degrade calcareous skeletons by mechanical fragmentation, bioerosion, maceration, and carbonate dissolution (Freiwald, 1998). One of the major processes is bioerosion, which degrades carbonate skeletal material and rocky limestone coasts in all marine and some freshwater environments (Wisshak et al., 2005). At the same time, it makes these materials more susceptible to mechanical abrasion, fragmentation, dissolution, and further bioerosion (Young \& Nelson, 1988; Mloszewska, 2014).

Bioerosion led by cyanobacteria (i.e. microbioerosion) occurs in terrestrial, freshwater, and marine environments, and depends on several ecological and climatic conditions (Schneider \& Le Campion-Alsumad, 1999). As cyanobacteria are organisms that hardly leave fossil record, the traces left by these organisms provide additional information about the environment. In fact, actuo-paleontological studies, which relate traces with the biological entities, are important because provide by analogy paleoenvironmental context to these references (e.g. Vogel et al., 1987; Radtke, 1991; Glaub, 1994; Radtke \& Golubic, 2005). In fact, there is a number of boring cyanobacteria described for freshwater environments (Tribollet et al., 2008; Lawfield et al., 2014). However, an ichnotaxonomical assignment of traces, and the taxonomic identification of the trace-producing cyanobacteria in these ecosystems are still lacking.

In freshwater environments dissolution has been pointed as the main process affecting shell surface (Cummins, 1994; Kotzian \& Simões, 2006; Nielsen et al., 2008). In the particular case of Argentina, Tietze \& De Francesco (2014) concluded that the main process affecting shell surface was dissolution, due to the granular texture and loss of original color and luster observed in shells. This is mainly attributed to biological dissolution through de decomposition of organic matter that release carbon dioxide, organic acids, methane and alcohols, which favor dissolution of carbonate remains and/ or microbioerosion.

This is the first contribution in the region regarding the identification of fossil lentic paleoenvironments through cyanobacteria ichnotaxa. The aim of this work is to 
communicate the first record of a trace left by a cyanobacteria in a shallow lake of the Pampean Region of Argentina, and to analyze its implication for the fossil record, improving the paleoecological interpretations.

\section{STUDY AREA}

The Pampas are a vast grassy plain that covers central Argentina. From a geological and geomorphological point of view, the Pampean Region is a heterogeneous environment. The geomorphology of the Pampean Region produce a slow drainage of surface water, allowing the formation of a great number of lentic systems (Fernández Cirelli \& Miretzky, 2004). These lakes are very shallow, with low permanence of water and highly variable salinity, and naturally eutrophic. They are permanent or transitory waterbodies that are located in a basin of well defined outline, and lack permanent thermal and chemical stratification, with sediments different from the surrounding land (Grosman, 2008). Lake basins were originated during the Late Pleistocene by the action of the prevailing westerly winds (westerlies). With the onset of moister Holocene conditions, these depressions became areas of groundwater discharge and surface-water accumulation, being filled gradually with sediments that contain abundant mollusk shells (Stutz et al., 2010; De Francesco et al., 2013).

La Brava Lake, a representative Pampean waterbody, was selected for this study (Figure 1). It is one of the few permanent freshwater shallow lakes of the area (Irurzun et al., 2014), located in the northern area of the Tandilia range, 42 $\mathrm{km}$ far from Mar del Plata city $\left(37^{\circ} 52^{\prime} \mathrm{S}, 57^{\circ} 59^{\prime} \mathrm{W}\right)$. This shallow lake has an area of $4 \mathrm{~km}^{2}$, a maximum depth of $4.75 \mathrm{~m}$ and is classified as bicarbonate-sodium oligohaline (Romanelli et al., 2010). Like others waterbodies of the region, it is immersed in crop-livestock agroecosystems (Romanelli et al., 2011).

\section{MATERIAL AND METHODS}

During summer and winter of 2015 shells of the mollusks Heleobia parchappii (d'Orbigny, 1835) and Biomphalaria peregrina (1835) were collected in the littoral zone of La Brava Lake. The specimens collected were specially picked when the biofilm covered the shell externally or dissolution marks were observed; however, a few shells without any cover were also collected. This was performed in order to analyze

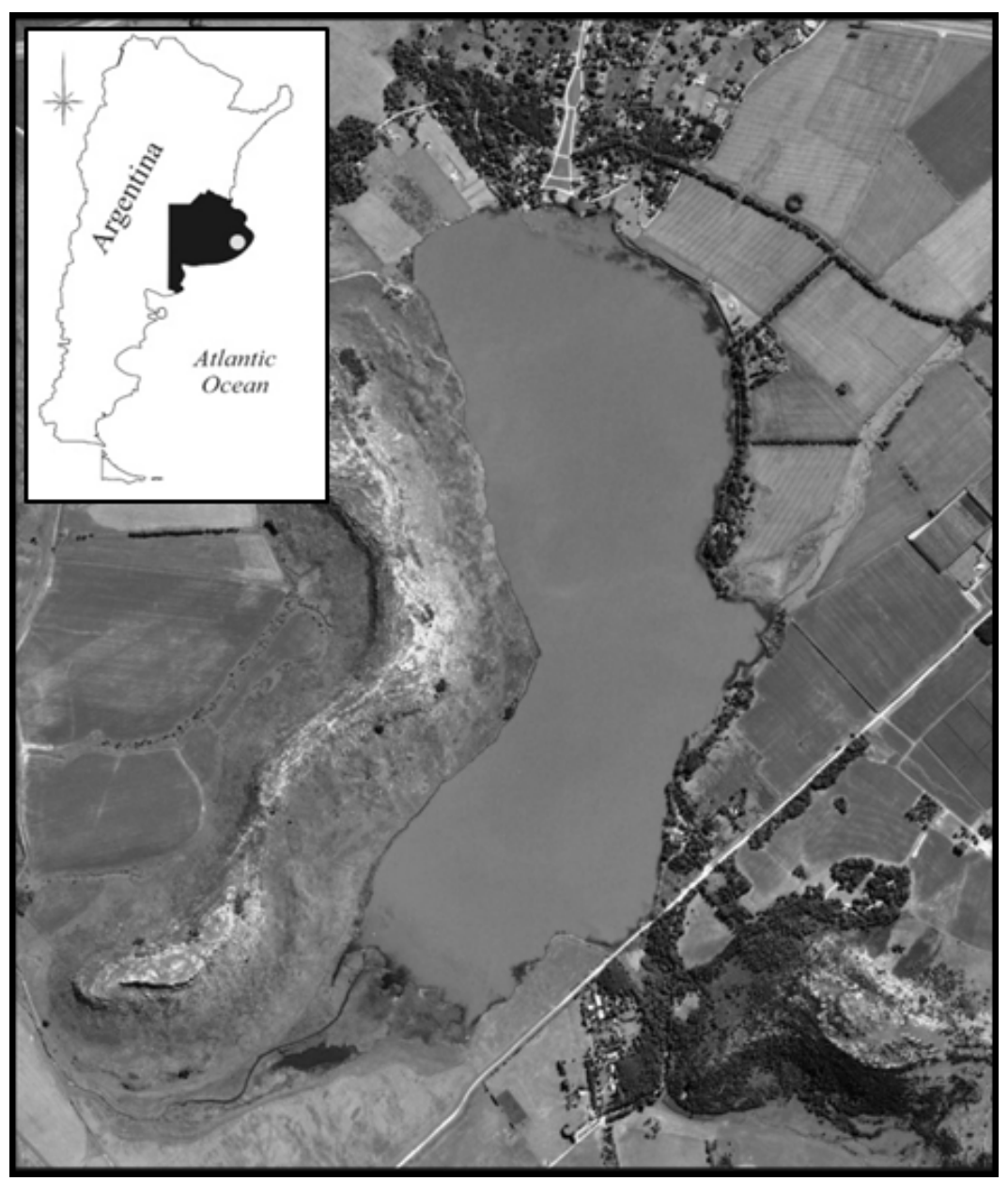

Figure 1. Map of the study site: La Brava lake. 
the different shell surfaces under this three conditions, and to know if microbioerosion was associated to the presence of biofilm. Samples were stored in alcohol $70^{\circ}$ and carried to laboratory. Shell surface of some specimens were scrapped, and the removed biofilm was observed under light microscope. In some cases, shells were dissolved using dilute $\mathrm{HCl}(5 \%)$ in order to determine the presence of euendolithic species, and observe them under light microscope. Other specimens were treated with sodium hypochlorite $2.5 \%$ to remove organic matter, and then coated with gold and analyzed using scanning electronic microscope (SEM) at the Laboratory of Microscopy of the National University of Mar del Plata.

\section{RESULTS AND DISCUSSION}

This note corresponds to the first record of microbioerosion borings in shells of Heleobia parchappii, and the presence of trace producing cyanobacteria. Taphonomic decay of studied shells was noted, with the external periostracum and prismatic aragonite layers deteriorated (Figure 2A). The presence of a biofilm covering the shells do not determinate the presence of euendolithic cyanobacterias, i.e., shells presenting biofilm were observed under SEM and its surfaces were intact.

Surface pitting and circular to ovoid penetrations were observed at SEM in some shells presenting signs of dissolution at naked eye (Figures 2B-D). The circular and subcircular penetrations are interpreted as the aperture of deep endolithic perforations on the shell. These shells also presented loss of proteinaceous parts (periostracum), and most of them presented signs of fragmentation. These taphonomic features are very common in shells deposited in dead assemblages in freshwater systems of the Pampean Region (Tietze \& De Francesco, 2014, 2017) suggesting that the shells presenting microbioerosion do not seem to be older than the other ones collected. However, time-averaging studies in pampean lakes are still missing. The longitudinal tunnels, which end in circular to ovoid apertures, were present throughout the shell, ending in the internal and external layers. Euendolithic filamentous cyanobacteria were found when shells were observed at light microscope and

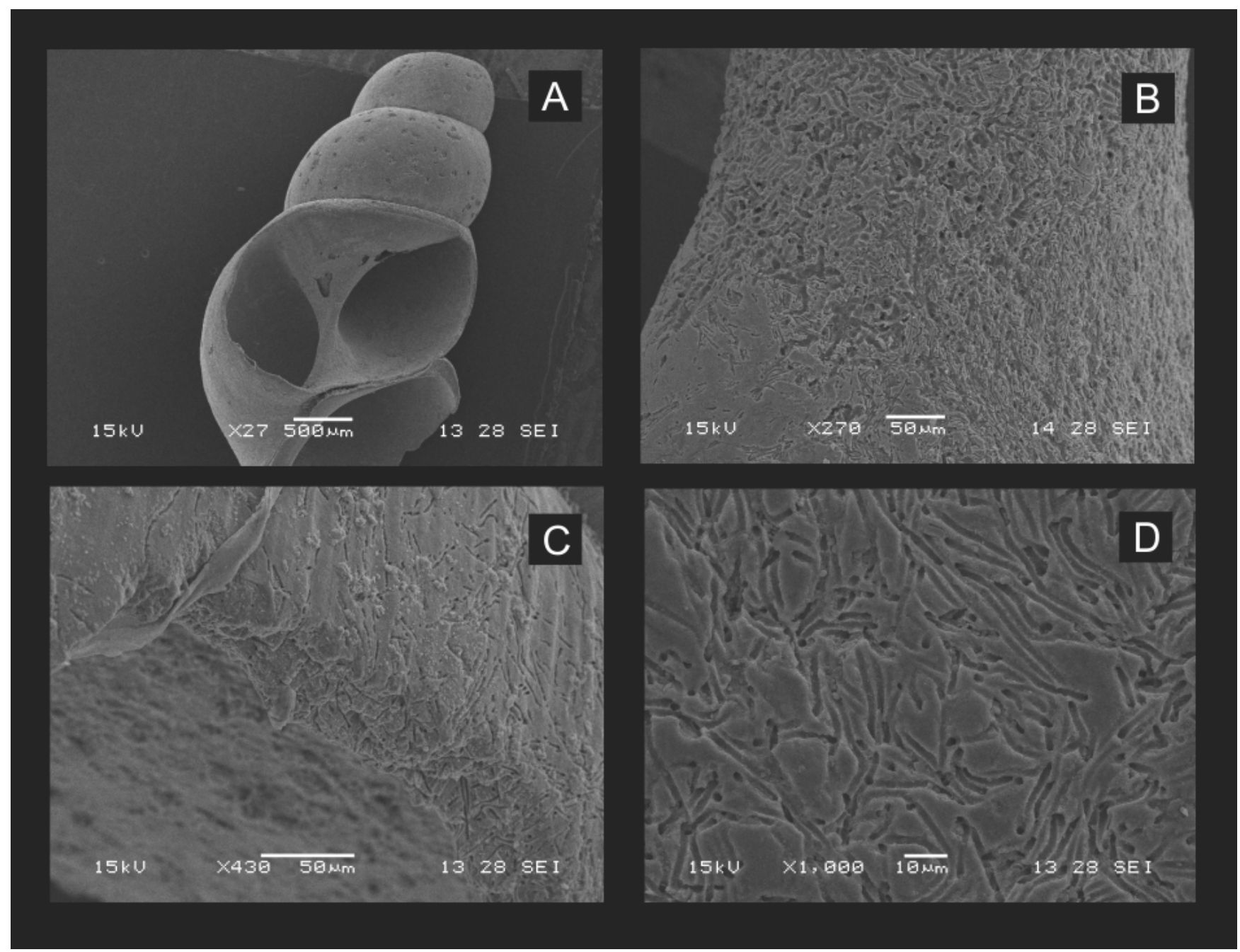

Figure 2. Photographs at scanning electronic microscope of Heleobia parchappii shells. A, shell surface; B-D, tunnels and ovoid to circular pitting caused by euendolithic cyanobacteria. 
SEM. Cyanobacteria cells are arranged in uniseriate straight trichomes enveloped by a fine and mucilaginous sheath (mean filamentous wide: $2 \mu \mathrm{m}$ ) (Figures 3A-B). Trichome cells are longer than wide; long: $2.15-4.8 \mu \mathrm{m}$ (mean: $3.13 \mu \mathrm{m}$ ); wide: $0.93-1.5 \mu \mathrm{m}$ (mean $1.1 \mu \mathrm{m}$ ), and present constrictions at the cross walls. Apical cells are longer than trichome ones (mean long: $4 \mu \mathrm{m}$ ) with rounded ends. Cells sizes of trichome were confirmed at SEM long: 2.14-5.4 $\mu \mathrm{m}$ (mean: $3.77 \mu \mathrm{m}$ ); wide: 1.46-1.9 $\mu \mathrm{m}$ (mean: $1.71 \mu \mathrm{m}$ ) (Figures 3C-D).

Previous studies of mollusk preservation performed in the region highlight the importance of destroying processes in the freshwater environments (Cristini \& De Francesco, 2012; Tietze \& De Francesco, 2012, 2014, 2017). One of the taphonomic attributes most commonly found in shells is the 'fine-scale surface alteration' (defined by Best \& Kidwell, 2000), an attribute that combines the alteration produced by dissolution, abrasion and microbioerosion, at low magnification. This feature is generally attributed to dissolution due to the subsaturation of calcium carbonates found in freshwater environments. However, pampean shallow lakes are highly productive environments (i.e. naturally euthrophic lakes) where shells are prone to be affected by dissolution associated to decomposition of organic matter and/ or microbioerosion processes. Therefore, it is important to discern among the alterations produced by different processes. In accordance, this contribution highlights the importance of considering microbioerosion as a process affecting shell preservation in shallow lakes of the region.

The endolithic cyanobacteria found in Heleobia parchappii shells could be identified as belonging to the family Pseudanabaenaceae (Komárek \& Anagnostidis, 2005). However, future molecular studies are needed to identify at the genera or species level the microorganisms that generate the traces. The identification of the cyanobacteria will allow to know the ecological requirements of these microorganisms, enhancing the paleoecological interpretations done in shallow lakes of the region, because physico-chemical parameters (temperature and salinity, as examples) affect the presence and distribution of certain euendoliths (Gektidis et al., 2007). Besides, microendoliths occur over a wide range of salinities, from hypersaline to freshwater environments, implying the feasibility of applying microboring trace fossils as paleosalinity indicators if different species are found (Wisshak, 2012).

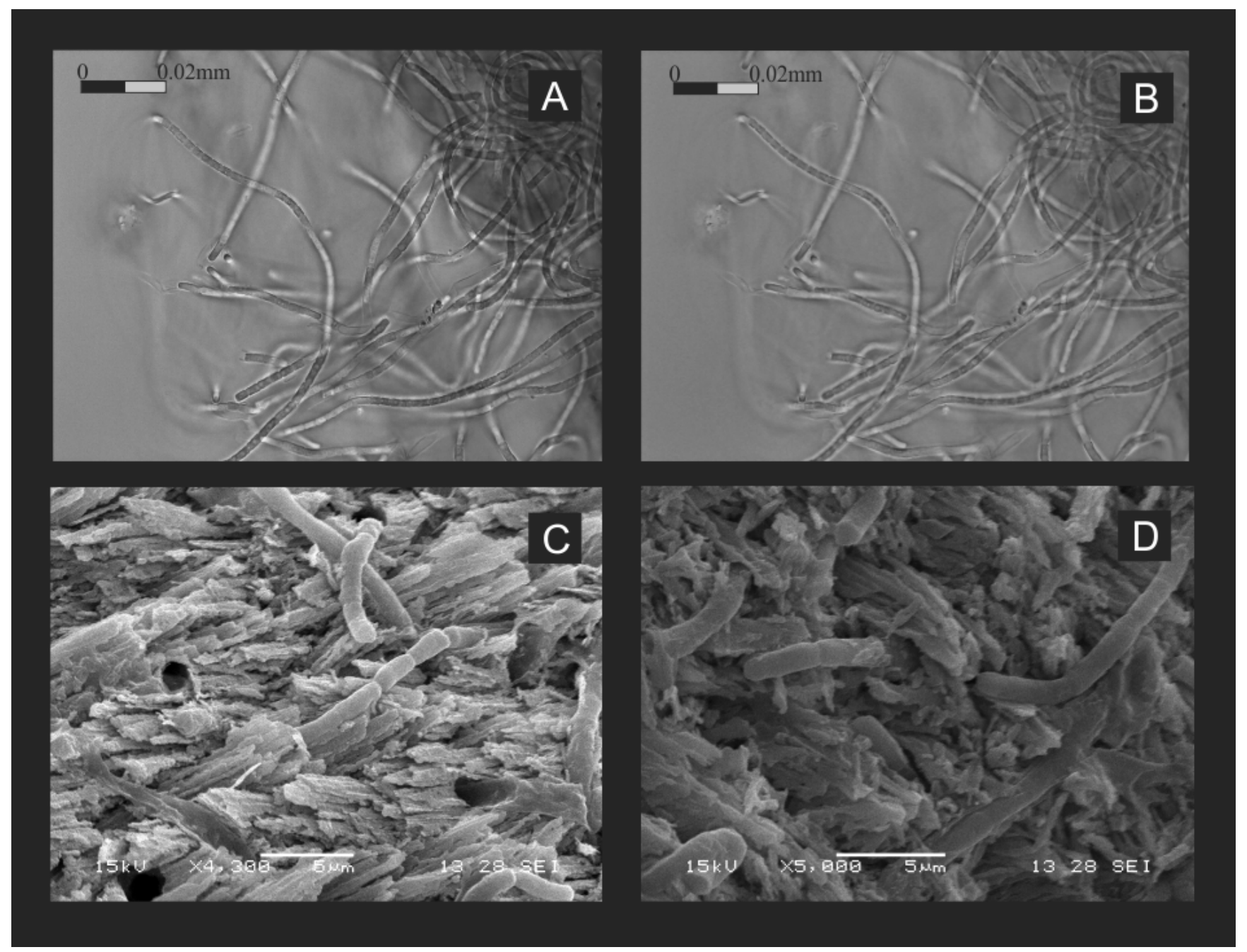

Figure 3. Photograph at light (A-B) and scanning electronic (C-D) microscopes of cyanobacteria filaments found in Heleobia parchappii shell surface. 


\section{CONCLUSION}

This work describes a new finding of microbioerosion in shells of freshwater mollusks of Pampean shallow lakes, characterized by surface pitting and circular to ovoid penetrations. The tunnels were present throughout the shell, ending in the external and internal surfaces. Genetic analysis would be necessary to identify correctly the endolithic cyanobacteria species. The record of this endolithic bioerosion trace enhances the discussion of taphonomic processes affecting mollusk shells in freshwater settings, and may allow to adjust the composition of fossil assemblages. In the future it would be interesting to perform a study comparing the microbioerosion among different lakes (different salinity levels as an example) and find out if the same or different species of euendolithic species are present in the different environments, allowing their differentiation in the fossil record.

\section{ACKNOWLEDGEMENTS}

We are indebtedly grateful to S. Golubic, R. Echenique and J. Komárek for helping us with the taxonomic identification of the cyanobacteria. We also thank the three reviewers S. Richiano, M.N. Ritter and V.R. Werner for the helpful comments made on the original version of this manuscript which greatly improved it. This work was supported by Agencia Nacional de Investigación Científica y Tecnológica (PICT 2013-0564).

\section{REFERENCES}

Best, M.M.R. \& Kidwell, S.M. 2000. Bivalve taphonomy in tropical mixed siliciclastic-carbonate settings. I. Environmental variation in shell condition. Paleobiology, 26:80-102. doi:10.1666/00948373(2000)026<0080:BTITMS >2.0.CO;2.

Cristini, P.A. \& De Francesco, C.G. 2012. Análisis tafonómico de moluscos por debajo de la interfase agua-sedimento en la laguna Nahuel Rucá (Provincia de Buenos Aires, Argentina). Ameghiniana, 49:594-605. doi:10.5710/AMGH.1.12.2012.352

Cummins, R.H. 1994. Taphonomic processes in modern freshwater molluscan dead assemblages: Implications for the freshwater fossil record. Palaeogeography, Palaeoclimatology, Palaeoecology, 108:55-73. doi:10.1016/0031-0182(94)90022-1

Davies, J.D.; Powell, E.N. \& Staton, R.J. 1989. Relative rates of shell dissolution and net sediment accumulation - a commentary: can shell beds form by the gradual accumulation of biogenic debris on the sea floor? Lethaia, 22:207-212. doi:10.1111/j.1502-3931.1989.tb01683.x

De Francesco, C.G.; Tietze, E. \& Cristini, P.A. 2013. Mollusk successions of Holocene shallow-lake deposits from the southeastern pampa plain, Argentina. Palaios, 28:851-862. doi:10.1111/j.1502-3931.1989.tb01683.x

Fernández Cirelli, A. \& Mirezky, P. 2004. Ionic relations: a tool for studying hydrogeochemical processes in Pampean shallow lakes (Buenos Aires, Argentina). Quaternary International, 114:113-121. doi:10.1016/S1040-6182(03)00046-6

Freiwald, A. 1998. Microbial maceration and carbonate dissolution on cold-temperate shelves. Historical Biology, 13:27-35. doi:10.1080/08912969809386570
Gektidis, M.; Dubinsky, Z. \& Goffredo, S. 2007. Microendoliths of the shallow euphotic zone in open and shaded habitats at $30 \mathrm{~N}$ Eilat, Israel: paleoecological implications. Facies, 53:43-55. doi:10.1007/s10347-006-0091-z

Glaub, I. 1994. Mikrobohrspuren in ausgewählten Ablagerungsräumen des europäischen Jura und der Unterkreide (Klassifikation und Palökologie). Courier Forschungsinstitut Senckenberg, 174:1-324.

Grosman, F. 2008. Una invitación a conocer las lagunas pampeanas. In: F. Grosman, (ed.) Espejos en la llanura. Nuestras lagunas de la región pampeana. Universidad del Centro de la provincia de Buenos Aires, p. 19-38.

Irurzun, M.A.; Gogorza, C.S.G.; Sinito, A.M.; Chaparro, M.A.E.; Prieto, A.R.; Laprida, C.; Lirio, J.M.; Navas, A.M. \& Nuñez, H. 2014. A high-resolution palaeoclimate record for the last 4800 years from lake la Brava, SE pampas plains, Argentina. Geofísica Internacional, 53:365-383. doi:10.1016/S00167169(14)70072-8

Komárek, J. \& Anagnostidis K. 2005. Süßwasserflora von Mitteleuropa. Cyanoprokaryota. 2. Teil: Oscillatoriales. München, Elsevier GmbH, 758 p.

Kotzian, C.B. \& Simões, M.G. 2006. Taphonomy of recent freshwater molluscan death assemblages, Touro Passo Stream, Southern Brazil. Revista Brasileira de Paleontologia, 9:243-260.

Lawfield, A.M.W.; Gingras, M.K. \& Pemberton, G.S. 2014. Microboring in a freshwater fluvial unionid bivalve substrate. Ichnos, 21:193-204. doi:10.1080/10420940.2014.934190

Mloszewska, A.M. 2014. A multidisciplinary investigation on the influence of archean seawater composition and $U V$ radiation levels on the survival and evolution of early microorganisms. University of Alberta, Ph.D. Thesis, 399 p.

Nielsen, J.K.; Helama, S. \& Nielsen, J.K. 2008. Taphonomy of freshwater mollusks in carbonate poor deposits: a case study of the river pearl mussel in northeastern Finnish Lapland. Norwegian Journal of Geology, 88:103-116.

Radtke, G. 1991. Die mikroendolithischen Spurenfossilien im Alt-Tertiar West-Europas und ihre palokologische Bedeutung. Courier Forschungsinstitut Senckenberg, 138:1-185.

Radtke, G. \& Golubic, S. 2005. Microborings in mollusc shells, Bay of Safaga, Egypt: morphometry and ichnology. Facies, 51:118-134. doi:10.1007/s10347-005-0016-02

Romanelli, A.; Massone, H.E. \& Escalante, A.H. 2011. Stakeholder Analysis and Social-Biophysical Interdependencies for Common Pool Resource Management: La Brava Wetland (Argentina) as a Case Study. Environmental Management, 48:462-474. doi:10.1007/s00267-011-9698-0

Romanelli, A.; Quirós Londoño, O.M.; Massone, H.E.; Martinez, D.E. \& Bocanegra, E. 2010. El agua subterránea en el funcionamiento hidrológico de los humedales del Sudeste Bonaerense, Provincia de Buenos Aires, Argentina. Boletín Geológico y Minero, 121 (4):373-386.

Schneider, J. \& Le Campion-Alsumard, T. 1999. Construction and destruction of carbonates by marine and freshwater cyanobacteria. European Journal of Phycology, 34:417-426. doi:10.1080/09670269910001736472

Stutz, S.; Borel, C.M.; Fontana, S.L.; del Puerto, L.; Inda, H.; GarcíaRodríguez, F. \& Tonello, M.S. 2010. Late Holocene climate and environment of the SE Pampa grasslands, Argentina, inferred from biological indicators in shallow, freshwater Lake Nahuel Rucá. Journal of Paleolimnology, 44:761-775. doi:10.1007/ s10933-010-9450-4

Tietze, E. \& De Francesco, C.G. 2012. Compositional fidelity of subfossil mollusk assemblages in stream and lakes of 
the southeastern pampas, Argentina. Palaios, 27:401-414. doi:10.2110/palo.2011.p11-124r

Tietze, E. \& De Francesco, C.G. 2014. Taphonomic differences in molluscan shell preservation in freshwater environments from southeastern pampas, Argentina. Palaios, 29:501-511. doi:10.2110/palo.2014.019

Tietze, E. \& De Francesco, C.G. 2017. Compositional fidelity and taphonomy of freshwater mollusks from three pampean shallow lakes of Argentina. Ameghiniana, 54:208-223. doi:10.5710/ AMGH.18.10.2016.3022

Tribollet, A.; Veinott, G.; Golubic, S. \& Dart, R. 2008. Infestation of the North American freshwater mussel Elliptio complanata (Head Lake, Canada) by the euendolithic cyanobacterium Plectonema terebrans Bornet et Flahault. Algological Studies, 128:65-77. doi:10.1127/1864-1318/2008/0128-0065

Vogel, K.; Golubic, S. \& Brett, C.E. 1987. Endolith associations and their relation to facies distribution in the Middle Devonian of New York State, USA. Lethaia, 20:263-290. doi:10.1111/j.1502-3931.1987.tb02047.x

Wisshak, M. 2012. Microbioerosion. In: D. Knaust \& R.G. Bromley (eds.) Developments in sedimentology, Elsevier, p. 213-243. doi:10.1016/B978-0-444-53813-0.00008-3
Wisshak, M.; Gektidis, M.; Freiwald, A. \& Lundalv, T. 2005. Bioerosion along a bathymetrical gradient in a cold-temperate setting (Kosterfjord/SW Sweden): an experimental study. Facies, 51:93-117. doi:10.1007/s10347-005-0009-1

Young, H.R. \& Nelson, C.S. 1988. Endolithic biodegradation of cool-water skeletal carbonates on Scott shelf, northwestern Vancouver Island, Canada. Sedimentary Geology, 60:251-267. doi:10.1016/0037-0738(88)90123-6

Received in 26 November, 2017; accepted in 14 June, 2018. 
